\title{
Research on the Network Marketing of Agricultural Products
}

\author{
Bao Jianmei \\ School of Economic and Management \\ Shenyang Aerospace University \\ Shenyang, China
}

\author{
Liu Chen \\ School of Economic and Management \\ Shenyang Aerospace University \\ Shenyang, China
}

\begin{abstract}
Along with the application and development of E-commerce in all sectors of the society, the agricultural development in China has entered into a new era. The appearance of network marketing of agricultural products will inevitably bring along with a glittering array of opportunities, which has a significant meaning for promoting the agricultural marketing. Network marketing of agricultural products is established based on the internet, aiming to carry out marketing campaign with its characteristics, which can greatly decrease the cost of selling agricultural products, effectively enhance product competitiveness and raise the income of farmers. Under the new environment of China's entering into WTO, ecommerce has become an effective method for agricultural products to improve the international competitiveness, which is also beneficial to construct new countryside, increase income for farmers and at the same time to build a modernized countryside.
\end{abstract}

Keywords- Network Marketing; Agricultural products; Marketing Mode.

\section{INTRODUCTION}

In pace with the deepening of agricultural marketization, agricultural supply developed from national shortage to structural surplus and there is a contradiction between architecture of supply to demand structure with a large amount of agricultural products hoarding without selling out. Therefore, agricultural enterprises have to focus on agricultural products marketing.

At present, the trade of agricultural products is still in the stage of face-to-face spot transaction, and the agricultural market information is not updated quickly while the marketing channels are not smooth, all which shall have negative effects on the agricultural products marketing. As a result, it is difficult for the traditional marketing system to adapt to new market trend. So, agricultural enterprises shall vigorously develop network marketing, and the innovation of agricultural network marketing and marketing policy based on the internet shall be one of the keys to promote the agricultural product sale and enhance competitiveness.

\section{PRESENT SITUATION ANALYSIS OF NETWORK MARKETING OF AGRICULTURAL PRODUCTS}

\section{A. Development status of China's agricultural}

China has always been an agricultural nation since ancient times, and agriculture has appeared at the end of early Stone Age. Nowadays, peasant population has occupied $70 \%$ of the total population, yet facilities of agriculture still lag behind comparing to develop countries. If we cannot free from the traditional mode of production and development, then the single sale channel along with inadequate information and high transaction cost shall restrain the growth of China's agriculture

The development of modern civilization has changed people's concept and consumption pattern. And features of customers' current demands show as follows: 1. Personalized needs; 2. Strengthened initiative; 3. Pursue shopping enjoyment and convenience. Judging from marketing needs, network marketing is able to provide latest information about cheapest goods in competitive prices to satisfy their individual needs and further realize the interaction with customers. According to statistics, the number of internet users ranks third throughout the world with a faster growth scale, which indicate that network marketing of agricultural products shall have a large number of potential customers, and it is beneficial to the growth of it. In terms of characteristic structure, the rate of males, unmarried, less than 25 years old, with a junior college diploma or below, month salary less than 2000 Yuan (including those without income) are accordingly 60 . 4\%, 56.8\%, 52 . 9\%, 70 . 2\%, 77 . $6 \%$, and the rate of male internet users has increased comparing to half a year ago. In addition, $32 \%$ internet users are teachers, students and computer professionals while $34 \%$ are people who are engaged in party and government offices, news media, finance, insurance; $26 \%$ users serve in the tertiary industry such as trade and commerce, post and communications, etc; $7 \%$ users are workers while famers occupy less than $1 \%$. Besides, based on income situation, the result is shown in the figure below: Families with per capita income from 1000 to 2000 occupy $54 \%, 500$ to 1000 occupy 


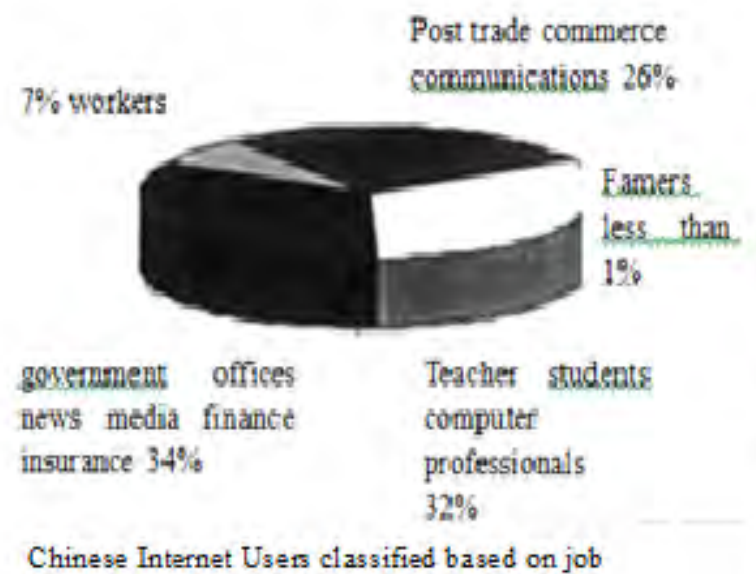

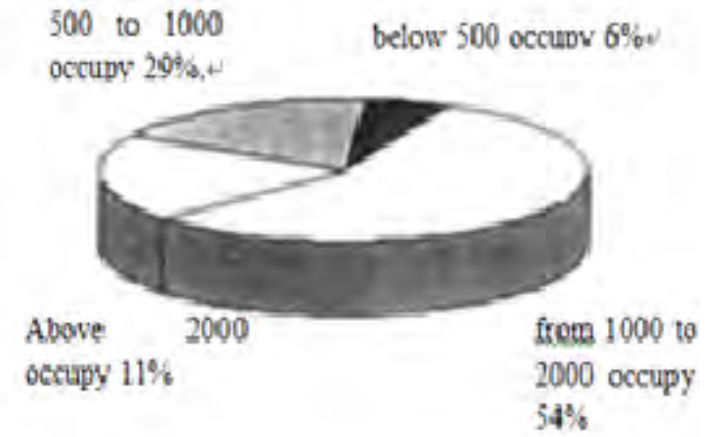

Chine se Internet Users classified based on per capita

Figure 1. Job classification and per capita distribution of Chinese internet users Note: Data sources: China Network Marketing

Chinese Internet Users classified based on job

Chinese Internet Users classified based on per capita

The above data shows that the future of network marketing of agricultural products shall be promising. Besides, family and company users rank top among all users, and most of them are from urban areas dominated by those from governmental office, school and computer media, finance industry, who are ultimate purchasers of agricultural products.

Weak foundation, rare access for farmers to surf online

\section{B. Existing Problems of network marketing of agricultural products}

However, network marketing of agricultural products is still at an early age with many restrictions, which limit its development.

\section{1) Weak foundation, rare access for farmers to surf online}

The network infrastructure of rural area and agriculture is weak and lags behind. What's more, the online trading is unreliable with a single mean of payment without a mature credit system and there is a deviation on the understanding and application of network marketing. In addition, people's internet consciousness is light and the consumption habit and system remain to be established. Furthermore, public policies fail to keep up with the development, so there is a dazzling array of problems such as tariffs issue, right of privacy, tax problems, legal problems, etc, all which will hinder the development of the application and development of network marketing of agricultural products.
China has a 900 million rural population, occupying $75 \%$ of the total population, yet only $0.3 \%$ of them have access to the internet. Similar to the topographical distribution, regions adopt digital technique demonstrate a rundle distribution with an adverse direction, namely the eastern region is developed in terms of digital technology while central and western regions are under developed. Both the real internet users and related ratio, the number of people have access to internet in eastern regions is larger. There is no detailed statistics of rural internet users, yet there are detailed statistics of certain provinces.

2) Low educational level, lack of qualified personnel to promote the network marketing of agricultural products

Most of Chinese farmers have low education level, and they are rarely exposed to modern agricultural technology, high-tech communication, internet recognition and application. Besides, their living habits, work style and values cannot keep up with the global information age, which makes it difficult for them to carry out manufacturing and sales with advanced tools. As a result, the production volume and quantity standard cannot be in accordance with the demand of the market without competitiveness. As far as I am concerned, the educational background is an important measure for their cultural and scientific qualities.

3) Low degree of standardization

The online agricultural products should meet the requirement of standardization in terms of quality, packing and product code. Practice of foreign network marketing has show that products with reputation, standard specification, easy to distribute shall have a better result to while conducting promotion and sales. 


\begin{tabular}{ccccc}
\hline Year & 1990 & 1995 & 2000 & 2005 \\
$\begin{array}{c}\text { illiterate and } \\
\text { semiliterate person }\end{array}$ & 20.73 & 13.47 & 8.09 & 8.58 \\
Primary school & 38.86 & 36.62 & 32.22 & 28.83 \\
Junior high school & 32.84 & 40.11 & 48.07 & 51.66 \\
Senior high school & 6.96 & 8.61 & 9.38 & 10.31 \\
Junior college and & 0.10 & 0.24 & 0.40 & 0.62 \\
above & & & & \\
\hline
\end{tabular}

\section{4) Immature logistics system}

Note: Data resources: To prepare according to China Rural Statistics Rural Book of relevant years

Logistics is an important sector during the transaction, which takes the responsibility to deliver the goods to customers. So effective and qualified logistics service are important guarantees to full play the advantages of network marketing, however, there are many problems in terms of logistics distribution. To begin with, there are rare large logistics companies which are able to deliver goods throughout the nation, and many logisticians have low diathesis without a strong sense of service consciousness. There are many unhappy things happened during their connections with customers, which directly decrease customers enthusiasm and favor and further decrease people's willing to carry out online purchases

5) Security Problems.

The secure and universal electronic money is still in the stage of exploration and manufacturing because credit cards have not accepted by the main market. And those transactions can only be paid in advance or afterwards. Even though particular banks have started to carry out network marketing, there is a still a long way to go for overall network marketing. Therefore, electronic payment shall be paid attention to by the whole society.

\section{ANALYSIS ON THE STRATEGIES AND DEVELOPMENT TREND OF THE NETWORK MARKETING OF AGRICULTURAL PRODUCTS}

\section{A. Development strategies of network marketing of agricultural products}

Strengthen the rural information construction. Agricultural information network investment is the basis of network marketing. It shall regard the information technology modernization as the goal to strengthen network information construction, increase the popularity of internet, and at the same time strengthen the development and construction of agricultural information resources. What's more, through the introduction of relevant preferential policies, we can help manufactures, vendors and farmers to surf online so as to promote network marketing of agricultural products.

Speed up the pace to make agricultural product quality standards. To implement agriculture standardized production is a new agricultural production idea which is in accordance with the requirements of market under the new times. In order to carry out network marketing of agricultural products, government should increase investment on the construction of agriculture standardized production, and speed up the pace to regulate related standards in terms of manufacturing, processing, packing, testing, etc, and put the standardized production and management into the whole process of agricultural production and sales.

Perfect the logistics system. People of rural areas have few accesses to information, so even if businessman are busy in purchasing agricultural products farmers are still trying to sell their products. Professional logistics enterprises shall possess strong economic strength and invest a large amount of money on information infrastructure, introduce advanced management idea and cutting-edge technology so as to satisfy people's needs on agricultural products with a more convenient way and lower price..

Strengthen network information supervision management. The development of network marketing of agricultural products cannot be realized depending on a certain industry, it is a complicated system engineering, which involves many sectors of social economy. Only by comprehensive arrangement by relevant departments, the network marketing shall have a smooth development. The function of government is mainly manifested in establishing institutional framework, market discipline, and legal system etc to regulate the network marketing behavior so as to lead it develop toward a healthy and orderly direction. 
Cultivate agricultural talents. Cultivate top talents to serve for the construction of agricultural information, propagate and train about the marketing knowledge to let farmers know the convenience and affordable nature of the internet so as to strengthen their marketing consciousness. What's more, the government should organize farmers to accept the internet training. Talent is the key to realize agriculture modernization. Only by intensifying the development of talents, enhancing network information idea, making full use of network resources, the network marketing can be promoted

\section{B. The development trend of network marketing of agricultural products}

This part shall analyze that the ratio of network marketing shall increase along with the reform of various towns and villages and the promotion of key agricultural products. What's more, it will also introduce the multi-dimensional development trend of urban development, agricultural products brand foster, agricultural enterprise scale industrialization, and specialization of agricultural park.

Increased demand of network marketing based on urbanization process. In the past ten years, the population proportion of prefecture-level cities has constantly increased. In addition, with the strengthening consciousness, the end market has put forward new requirements on green and organic agricultural product. However, products manufacturing in various regions is at a small scale, and is during the transitional stage from fragmented structure to scale-farming structure. And the network marketing strategies make up for the demerits of fragmented structure. Besides, with the increasing number of internet consumers, they ask higher requirements on the quality and convenience of agricultural products and network marketing collect information of these kinds of end markets to replace the original marketing channels.

A series of influential network marketing platforms shall be added. Brand construction is one of the major tasks of marketing, while famous and trustworthy platforms shall inspire customers' confidence in these brands to attract partners, competitors and suppliers, etc. What's more, brand construction shall add intangible values. For example, Jiangsu Province has launched many preferential policies based on the support by the government, and the leading agricultural enterprises have joined this platform to full play the role of network marketing. Besides, leading enterprises have inspired down-stream enterprises to join this platform. As a result, with more and more famous buyers, suppliers and distributors joining this platform, the number of targets shall boost. In the future, if enterprises and governmental offices of towns and villages can focus on the construction of brand connotation, a leading platform shall be established with the philosophy of integration and specialization.

The online-service of distinctive and organic food toward the urban requirement shall emerge. In network economic era, the number of internet users is increasing and people who have good economic base and good educational background ask for distinctive and organic food. Therefore, in surrounding areas agricultural park collecting organic agricultural products plating, online sales, ecological recreation, and family adventure experience, etc are established; and the land ownership are operated by some retail investors or run by foreign investment. In order to provide excellent online service, these management modes focus on the information collection and release of original materials selection, planting process, products exchange to recruit outstanding talents of agricultural products manufacturing, and network marketing so as to regulate the production flow and perfect the online transaction system.

\section{CONCLUSION}

Network Marketing, as a new marketing mode nowadays only exists for a short time, yet with a very extensive prospect of development. It has provided a broader platform to sell agricultural product. Besides, related development and application have injected new vigor into agriculture. To deliver goods from visual transaction to practical deal with advanced internet technology, and logistics means is the trend of history, and the world economy, which shall have a profound effect on the rural economic development. Even though this new marketing mode will face constraints and obstacles, it shall inevitably play a positive role with continuous changes of internet and consumption concept. In addition, agricultural production enterprises and individual have to grasp the opportunity, build their brand, keep up with times, vigorously promote this mode and establish a network marketing system

\section{REFERENCES}

[1] RAVI K, ANDREW B W. Frontiers of Electronic Commerce $[\mathrm{M}]$. Reading

Mass: Addison-Wesley, 2012: 75-87.

[2] CROWELL J F.Report of the Industrial Commission on the Distribution of Farm Products $[\mathrm{M}]$. Washington, D. C: Government Printing Office, 2011:32-34.

[3] WELD L D. Marketing of Farm Products [M]. New York, Macmillan, 2010:23-25

[4] Zeng Kunsheng, Analysis on Agricultural Product Marketing in Net Time [J]. Study of the Rural Modernization, 2012(3) : 176177

[5] Wang Wenchuan, Marketing Strategic Research of Agricultural Products[J] Shanxi Science and Technology,2013, (3) : 3-4.

[6] Xi Guoquan, Le Yueyun, Study on Brand Strategy of Chinese Agricultural Products [J]. Chinese Rural Economy, 2011, (9) : 65-68.

[7] Zhang Jinhua, Analysis on existing problems and countermeasures of Chinese agricultural products [J]. Science \& Technology Information, 2011, (5) : 11-12.

[8] Wang Wen Chuan, Marketing Strategic Research of Agricultural Products[J]. Shanxi Science and Technology,2012,(3) : 3-4

[9] Chen Zhengming. Analysis on Difficulties and Countermeasures of Increasing Farmers' Income, Southwest Finance, 2011, (2) : 44-45.

[10] Wang Wenjuan, Jin Shengfu, Liu Shenghai, Analysis on the Development of Network Marketing of Agricultural Products Expand the Channels of Agricultural Products' Circulation. Technology Forum 2013:67. 